\title{
FROM THE PRESENT TO THE PAST: REDEMPTIVE AUTHORITY OF HISTORY IN OCTAVIA BUTLER'S KINDRED
}

\author{
Koffi Eugene N'guessan \\ Alassane Ouattara University, Cote d'Ivoire
}

Citation: Koffi Eugene N'guessan (2022) From the Present to the Past: Redemptive Authority of History in Octavia Butler's Kindred, European Journal of English Language and Literature Studies, Vol.10, No.1, pp.1630

\begin{abstract}
The present paper aims to validate the idea that history is a foundational site of redemption. Through anachronistic traumatic journeys that take place in the present, Octavia Butler's Kindred establishes symbolic and critical connections between past and present. Using magical realism, a counter hegemonic style, the novel blurs binary oppositions, such as past and present, dominant and dominated, questioning notions of hierarchy and dominance, and above all subverting the official reality of slavery. In reenacting slavery, this historical narrative constructs a linkage across time and race, and conceives the relevance of the racial past. Drawing on the postmodern slave narrative framework, we trace the process whereby the main character submits to the position of slave and at the same time incorporates in the historical narrative representation her sense of selfher subjectification. This experiential position facilitates the construction of a counter hegemonic knowledge that undermines the master narrative of slavery.
\end{abstract}

KEY WORDS: history, magical realism, masochism, past, present, slavery, redemption

\section{INTRODUCTION}

Most of any present is made up of the past. History, as Mulhern insists, is for the most part continuity. It belongs to its complex material weight that it cannot be perpetually refashioned. And even when we do manage to transform it, its weight may still be found resting like a nightmare on the brains of the living (Eagleton, 2003: xii)

The ongoing practices of discrimination coupled with sporadic and continuous murders of blacks by whites indicate that racial boundaries still exist between both American ethnic groups. In this context of criminal history of modern racism, strategies and means toward racial equality still need to be worked out. In other words, there is still much to be done in order to reach effective racial equality in the United States. It is in that perspective that contemporary narratives of slavery are prominent today among African American writers. At the core of this revival of interest in slave narratives, the consuming question facing contemporary black literary studies has been according to Levy-Hussen (2016) how to conceptualize "the meaning and relevance of the racial past" (loc. 3185).

Historical knowledge or learning from the past seems to be a significant and quite fundamental step for illumination and resolution of the trauma of slavery. In what Octavia Butler proposes in her book, Kindred, there is a dynamic relationship between the past and the present, which, no doubt, holds from the author's intent and strong desire to illuminate so as 
to allow a better understanding of what has shaped African Americans into what they are. In that novel grounded in magical realism, with its perspective of negation and evaluation, the author insists upon the centrality of historical knowledge for racial liberation.

As a reverse journey which brings the past to the fore, Kindred is an inverse slave narrative symbolized under a different significance in order to challenge the differences between master and slave relationships. It is, as Ayobami Adebayo writes in the foreword of the electronic edition (2018), "a skillful examination of what it means to be human in a world that refuses to acknowledge that humanity" (loc. 87). Through hallucinations, which are narrative memories, the heroine tries to link the past to the present by delving into racial history and laying bare the social representations in the context of slavery. In this historical account of slavery that blurs the borderlines between reality and fiction, Dana, a contemporary heroine is pulled back into the past to confront a slave history, and the narrative itself is a retrospective account of Dana's flight from slavery to freedom.

Based on history that has inflicted trauma on black bodies, this contemporary narrative of slavery is made of the repetition or recurrence of past events, a reliving of trauma that collapses the past in the present. This re-enactment of the past enables a deeper understanding of the traumatic experiences Dana goes through in the narrative. In this study, I propose to examine and bring to light the redemptive power of historical memory. The guiding questions are therefore framed as follow: How does the historical narrative articulate Dana's redemption? What is the subversive role of the fantastic and how does Butler propose this decentering in Kindred?

Answering the above query, I wish to show Kindred as a liberative and suvivalist narrative in which Octavia Butler uses history as a source material to blur the traditional white/black boundaries. This study is therefore mainly concerned with an exploration of the way in which the narrative in Kindred structures, unravels the past and constructs the notion of self-identity using remembrance of the past. In subsequent sections, I elaborate on history as a narrative of liberation. First of all, I shall establish the enduring power of the past into the present and then articulate Dana's transformative historical return: her subjectification through submission.

\section{The Presentness of the Past or the Past in the Present}

In his How to Read African American Literature, Aida Levy-Hussen (2016) argues that, Kindred is a "fiction of racial remembrance" (loc. 162); that is, a contemporary narrative of slavery, which can be categorized as a speculative fiction. As a speculative fiction, it treats history as the source material for a reimagining of the social order. It belongs to the category of literature of subversion, a mode of writing that rejects Western system of representations and operates as a mode of transgression based on elements of the fantastic and the marvelous. This imaginative reconstitution is what is termed "magical realism."

An amalgamation of fact and fiction, magical realism combines the natural and the supernatural with the purpose of amending realism, or unsettling the official history for a new understanding of the world. It is based on a poetics of subversion, and according to Eugene L. Arva, (2020) "Magical realist writing aligns with the general postmodern view that rejects the 
existence of only one reality and one truth, and constantly exposes its own failure to achieve a thorough and accurate representation of the world" (19-20).

Magical realism is a category of writing anchored in defamiliarizing mechanism: the intrusion of the supernatural with the purpose of subverting the ontological stability of the real. As Cristina Şandru (2008) writes, "What is characteristic of magical realist texts is the way in which the transition between what is experientially possible in our world and what is empirically impossible is made seamless" (28). It contrasts with the writing of the real or the realistic representation such as history.

Following the postmodern politics of representation, the historical narrative in Kindred dissolves the official history of slavery. As a postmodern historical fiction, it is an embodied experience of the past, an active engagement with the past, which allows Dana, the main protagonist, not only to feel history: her traumatic family history, but also to shift from history to an "other" story of slavery with the perspective of overcoming trauma. Actually, what Dana tries to cope with throughout the narrative is a psychological experience, which is comparable to the psychoanalytical notion of "the return of the repressed." It functions like a "talking cure" therapy, which brings to the fore latent memories of slavery for the sake of recovery.

It is therefore a redemptive narrative which is manifest in the novel through magical realism wherein the boundary between past and present is blurred by time travel and the injury Dana bears in the present time. The result of this absence of frontier between past and present in Kindred is a "temporally fluid representation of the American slave system and its legacy in the twentieth century" (Spaulding, 2005: 30).

In Kindred the past is intimately related to the present and the novel can be categorized as a historical fiction, wherein historical return and redemption are prevailing issues. Right from the start, the author acquaints us with Dana Franklin, the heroine with a missing arm: the scar of an unredeemed loss and pain. This scar is a contemporary reminder of slavery, a cultural trauma which looms large in the novel, and makes it a historical trauma narrative. Moreover, this bodily injury is a trope of loss that shows that the past continues to haunt the present. In Silencing the Past, Michel Rolph Trouillot (1995) writes,

That U.S. slavery has both officially ended, yet continues in many complex forms - most notably institutionalized racism and the cultural denigration of blackness - makes its representation particularly burdensome in the United States. Slavery here is a ghost, both the past and a living presence; and the problem of historical representation is how to represent that ghost, something that is and yet is not (146-147).

Bringing history into the present, Butler reconstructs a family history, the personal and historical experiences of Dana, which bring the past to the fore through a performative utterance of trauma. In the present, Dana re-experiences traumatic past through a traumatic recollection. As Dominick Lacapra (2016) writes, "Trauma and its causes are indeed a prominent feature of history, which should not be airbrushed or denied" (378). In this narrative reconstruction of past events, Butler makes the past relevant to the present by 
stressing the continuity between past and present through the wound Dana bears. The wound is a legacy of slavery, the symptom of a damaging past.

Dana is a descendant of trauma survivors. She vicariously experiences suffering from her ancestors who have been slaves. In other words, as an indirect victim of cultural form of oppression, Dana is a survivor of the overwhelming experiences of slavery, and the hallucinations she has operate as symptoms of the traumatic life of her ancestors. When she vanished into the past for the first time and came back to herself, she says: "Maybe I'm just like a victim of robbery or rape or something - a victim who survives, but who doesn't feel safe any more. I don't have a name for the thing that happened to me, but I don't feel safe any more" (11). The logic of realism shrinks here and the fantastic takes over, and the whole novel is a speculative narrative, an alternative version of history, in which Dana is transported from the present to the past through hallucinations or dream visions. These hallucinations open the gate for Dana's firsthand experience of the past. They are ghostly voices that "kidnap" Dana from the present in order to imbue her with the past.

On a wider level, magical realism operates as a corrective to ideological dominance. In establishing a connection between her past and her present, Dana is simultaneously bridging her connection with her white ancestors, particularly with Rufus Weylin, a white slaveholder of the late nineteenth century. In this historical memory of the past, she feels a connection to Rufus that transcends their social, racial, and historical boundaries because they are "kindred." The idea of re-connection is subsequent to the idea of loss which is pervasive in the novel. In the prologue, Dana, reveals: "I lost an arm on my last trip home. My left arm. And I lost about a year of my life and much of the comfort and security I had not valued until it was gone" (1).

These losses Dana evokes are kinds of sacrifice, the price of her venture into the past. For her, as she later reports, it is an "accident," which has cost her the amputation of her arm. As a matter of fact, this physical scar is a site of memory as it is indicative of a symbolic, psychological and historical loss, translated in the form of Dana's unconsciousness following the accident. Coming back to herself, after the trauma of this bodily injury, she declares: "Finally, I awoke feeling able to talk to him [Kevin] coherently and understand what he said. I was almost comfortable except for the strange throbbing of my arm. Of where my arm had been. I moved my head, tried to look at the empty place...the stump" (1-2). In these opening lines of the novel, the loss occasions the traumatic opening of historicity, which makes its disruptive way into the present through hallucinations.

The loss is one evidence of racial oppression through slavery and it reveals one critical dimension of African American literature. Though the loss has become unconscious in the experience of blacks, it is still felt. Dana is profoundly marked by the wound, and the need for the remembrance of the past entails the telling of a story which involves a reformation of the self against collective history. That issue of loss calls for a racial memory, which in turn suggests a connection between the past and the present.

The interaction between past and present or the "conflation of time," according to a term by Timothy Spaulding (2005), starts at the beginning of the novel. For Dana, the loss is a site of 
an unconscious experience she started to experience exactly on her twenty-sixth birthday, and on the year of the two hundredth anniversary of the American independence, as she says: "The trouble began before June 9, 1976, when I became aware of it, but June 9 is the day I remember. It was my twenty-sixth birthday. It was also the day I met Rufus - the day he called me to him for the first time" (5). These lines signal a resurrection of the past in the present. Though the narrative of Dana's life begins with her anniversary in 1976, the whole novel is invaded by the past, which blurs the limit between past and present, and sometimes, leads Dana to confusion, as in the following:

I can understand that because most of the time, I'm still an observer. It's protection. It's nineteen seventy-six shielding and cushioning eighteen nineteen for me. But now and then, like with the kids' game, I can't maintain the distance. I'm drawn all the way into eighteen nineteen, and I don't know what to do. I ought to be doing something though. I know that.' (107)

The fusing between past and present is symbolized and vivified through the marital relation between Dana who is black and Kevin Franklin, a white man. This interracial couple blurs the boundary between whites and blacks, as well as it enlivens and encapsulates the consciousness of the past in the present. As Spaulding (2005) observes: "In essence, slavery affects Dana's life in the present on both physical and psychological terms. She must endure the legacy of slavery not only through her memories of her past experiences but also through its physical manifestations that persist even in her present life" (59).

Actually, both Dana and Kevin are descendants of perpetrators and victims of slavery. They are contemporary and historical characters affected by the effects and symptoms of this historical traumatic event inasmuch as their union is not accepted by their parents and relatives. This mutual rejection is a symptom of the past onto the present. In the present, the union between them bridges the gap between blacks and whites. Yet, their relationship is affected by racial tensions, by family disagreements; and the conflict that is persistent between Kevin's relatives and Dana's parents is rooted in the past. The gap between whites and blacks was wide and deep in the past, and especially during slavery. During slavery, interracial marriages were forbidden. In the present, Kevin's sister has rejected her brother's plan to marry Dana: “That she didn't want to meet you, wouldn't have you in her house - or me either if I married you. And she said a lot of other things. You don't want to hear them'" (118). On Dana's side, it is her aunt who does not like white people: "'You see? I told you they were old. She doesn't care much for white people, but she prefers light-skinned blacks. Figure that out. Anyway, she "forgives" me for you. But my uncle doesn't. He's sort of taken this personally" (120). These tensions clearly show the impact of slavery on the sexual politics of interracial relationships in the present.

In their present life, and for the police that came for an investigation following the incident that has led to the amputation of Dana's left arm, it is Kevin, her husband who hurt her. The neighbors heard Dana scream and thought she was being victimized by her husband, so they called the police. Because of this allegation of Dana's persecution by her white husband, the latter has been detained for a while before being released. However, whether Dana is a victim of racist oppression or not, the narrative does not make the point clear right from the start: 
'Good. I told them it was an accident. My fault.'

'There's no way a thing like that could be your fault.'

That's debatable. But it certainly wasn't your fault. Are you still in trouble?'

Thus, the past brings a paralysis and an irresolution onto the present. The comments and feelings of the community that surrounds the couple are beyond their time. To a considerable extent those feelings spring from their consciousness of the past. In other words, their attitude and feelings are guided by their allusion to the past. Neither Dana, nor Kevin has the least cognizance of the truth about the injury. Kevin pointedly uttered: "And heaven help me, Dana, I don't know.' And Dana: 'Neither do I,' I whispered. 'Neither do I' (4). In the wake of that traumatic loss, there is no definitive answer as to who is to assume responsibility for the wound, and it is this unresolved responsibility that triggers the beginning of an excavation of the past.

Dana's time travel is to connect with the past, trace out and comprehend the wound of slavery. The hallucinations experienced through her time travels blur the limit between the past and the present, as they allow Dana to live and act simultaneously in the past and in the present. The past surges up in the present as in the following scene where Dana is drawn from dream to reality, from the past to the present:

Pain dragged me back to consciousness. At first, it was all I was aware of; every part of my body hurt. Then I saw a blurred face above me - the face of a man - and I panicked. I scrambled away, kicking him, clawing the hands that reached out for me, trying to bite, lunging up toward his eyes. I could do it now. I could do anything.

'Dana!'

I froze. My name? no patroller would know that.

'Dana, look at me for God's sake!'

Kevin! It was Kevin's voice! I stared upward, managed to focus on him clearly at last. I was at home. I was lying on my own bed, bloody and dirty, but safe. Safe! Kevin lay half on top of me, holding me, smearing himself with my blood and his own. I could see where I had scratched his face - so near his eye (40-41).

In the dream she is confronted to the sexual assault of a patroller, and when she awakens with cuts and bruises, it is Kevin, her white husband who is leaning above her. Here, the connection between past and present or the destruction of the logical limits between past and present is made through the association of the patroller with Kevin. This kind of superposition shows that Dana is still in the position of a victim. It also appears through the physical comparison frequently exposed and established between Tom Weylin, the white plantation owner and Kevin, Dana's husband. The past therefore echoes its influence in present time, which closes the rift between past and present.

The wound of slavery makes the past contemporary; it resuscitates the past in the present. As in the foregoing, blacks and whites blame each other concerning the grievances of the past that they project onto the present. This irresolution emanates from ignorance or loss of memory, which predicates the desire for an investigation of the past. As a symptom of an 
unresolved suffering, the wound makes a bridge to the past: a link between the past and the present. In other words, through Dana's missing arm, a permanent mark of the past on her body, the past asserts itself in the present. Actually, the wound that she bears stands as the historical dehumanization of blacks that still exists today. It is symbolic of the pain caused by history, a metaphor of the physical, as well as mental and emotional trauma, the legacy of slavery on African Americans' life and living memory in general.

The wound of slavery constitutes the point of departure, the background of a new narrative of the past which is cast as an investigation based on anachronisms: a series of travels back and forth in time, a navigation through the past and the present. These anachronisms operate as a sort of hauntology, a kind of transgenerational phantom that evolves in the form of the return of the repressed and blurs the boundary between past and present. This historical archeology purports to dig into the past in order to discover the truth about the wound Dana bears. It is an exploration of the trauma, a revision of the slavery period in order for Dana to be a witness of the past and better understand it.

As a matter of fact, the historical narrative in Butler's Kindred takes a mythic form in which Dana oscillates between the past and the present, between two contradictory world orders through hallucinations. These hallucinations are a series of dream-like possessions, an antirealist mode that allows her to challenge and explore the problems of historical knowledge. In this historical narrative, the historical past is incumbent upon the present.

It stands to reason that the past affects the present. One's present is tied to the past. In his book entitled Silencing the Past, Michel Rolph Trouillot (1995) contends "What we know about slavery or about colonialism can - should, indeed - increase our ardor in the struggles against discrimination and oppression across racial and national boundaries" (150). Thus, bringing the past in the present in Butler's Kindred shows that history is a dynamic force, which has a strong hold onto the present.

From a present perspective and through time travel and anachronism, Butler connects the present with the past by linking contemporary characters: Dana and Kevin to the historical subject. As, Spaulding (2005) argues, "Butler's novel emphasizes the physical and psychological links between slavery and contemporary American life. Dana's body and her ancestral ties act as physical sites of the past that she must confront in order to free herself from slavery and its legacy" (26). The past history of slavery intrudes upon the present, and this suppression of the limit between past and present aims at reconstructing the history of slavery.

Thus, the narrative in Kindred is a kind of dialogue between past and present, between the real and imaginary worlds, which particularly insists on the presentness of the past, and operates as a return of the repressed. As the saying goes, before the past can be healed, it must be understood. Dana's present is overwhelmed by the burden of her ancestral history. Her present is linked to the past, at least to the survival of Rufus, her distant white ancestor. What effects do Dana's experiences in the past have on her life in the present? And how does she reclaim authority over the past in her historical memory? These are the guiding questions of discussion in the following section. 


\section{Submission and Subjectivity}

The form of Dana's self-subjection and the reconstruction process or transformative performance are the main focus in this section. By bringing the past in the present, Dana begins a healing process that starts imperatively with a form of servitude. How does the historical narrative articulate Dana's redemption? How does Dana resolve her silenced past, and establish peace with her traumatic loss? Historically, slave narratives aimed at liberating blacks from whites' oppressive and debasing system of slavery. As Claudia Tate (1998) argues, "The very purpose of the slave narrative was to justify the abolition of slavery by characterizing the humanity of the slave and the inhumanity of the peculiar institution" (3).

Kindred is a postmodern slave narrative, in which the author focuses on historical remembrance and knowledge, and interrogates the past's relationship to the present for the purpose of reconstruction and liberation. Drawing on the idea that, "in order to create a liberating present, one must first liberate the constraints of the past" (Spaulding, 2005: 23), this historical narrative which is performed through magical realism aims at redeeming the past. This redemptive return to the past, or the understanding and recovery from trauma, is predicated on the painful knowledge of Dana's personal and family historical events made of abuse and oppression.

In this process of the re-enactment of slavery, the author shows Dana's resilience and ability to survive. She is engaged in a journey of redemption that requires the reiteration of the past. In other words, Dana's redemption necessitates her connection with the past in order for her to establish relationship with her ancestors. Ultimately, this redemption rests on the recognition that she is more than an object, which paradoxically depends on her becoming a slave: mentally and physically.

Throughout the novel, Dana traces out and lives the experience of her family line, particularly her ancestors' past abuses: her great-grandmother Alice Greenwood and her white ancestor Rufus Weylin. Both will give birth to her grandmother Hagar Weylin. Dana is aware that without those historical characters' survival, she could not exist: "Was that why I was here? Not only to insure the survival of one accident-prone small boy [Rufus], but to insure my family's survival, my own birth" (24). She is therefore called upon preserving the life of her oppressor: "No matter what I did, he would have to survive to father Hagar, or I could not exist. That made sense" (24). The redemption calls for a deconstruction of object position to subject position. In this perspective of self-construction, Dana has to confront and survive transgenerational trauma by exposing herself to physical pain, as well as moral humiliation through an attitude of servility towards her instrumental white ancestors.

In other words, Dana's existence or self-preservation depends on a history of racial subjugation, therefore her submission. Working through generations of historical trauma is essential to her freedom in the present. Her relationship to the past is marked by a paradoxical investment in the oppressive system of slavery for an historical understanding that requires a turn to masochistic fantasy. As Aida Levy-Hussen (2016) notes in How to Read African American Literature, "Feeling historical pain is a requisite component of the fantasy of pain's alleviation" (Loc. 1064). He further indicates that it is a "masochistic fantasy intrinsic to the contemporary narrative of slavery" (Levy-Hussen, 2016, loc. 1064). 
Masochism is the satisfaction tied to the suffering or humiliation by the subject. In the case of Dana, her self-inflicted wound or masochistic performance operates through a juxtaposition of two opposing worlds. In the present, she is literate, free and in an interracial marriage. In the past, she adopts a different identity; she is constrained to be a submissive person. Her submissive attitude emanates from her willingness to stay sane and alive, as she says in the following passage:

I had come to almost welcome the hard work. It kept me from thinking. White people thought I was industrious. Most blacks thought I was either stupid or too intent on pleasing the whites. I thought I was keeping my fears and doubts at bay as best I could, and managing to stay relatively sane (178).

To forge a connection with the past, Dana's redemptive suffering pertains to moral masochism, which is defined by Laplanche and Pontalis (1973) as a derivative form of masochism, "where the subject, as a result of an unconscious sense of guilt, seeks out the position of victim without any sexual pleasure being directly involved" (224). For a better and broad understanding of slavery, which has a continuous resonance in the present, Dana accepts her subjugation by confronting the physical and psychological wounds of slavery.

As a matter of fact, Dana's masochistic attitude holds from a longing for recognition and survival. In the process of survivorship, she has developed stoicism. As she asserts, "The pain was a friend. Pain had never been a friend to me before, but now it kept me still. It forced reality on me and kept me sane" (122). Her submission is a condition for her liberation; that is the connection she has to establish between her and her white ancestors, in order for her to be recognized as a human subject. Actually, she does not seek pain. She seeks the pleasure that she feels she will deserve only after a period of suffering. As Levy-Hussein (2016) notes:

In the contemporary narrative of slavery, the desire for liberation is inextricably entwined with a desire for the reenactment of punishment and pain. This seeming contradiction occurs because the fantasy of liberation, of and from the slave past, is necessarily imagined as the telos of ancestral suffering. Thus, feeling historical pain is a requisite component of the fantasy of pain's alleviation. In a word, one finds a masochistic fantasy intrinsic to the contemporary narrative of slavery (Loc. 1069-1073).

In this reconstructive process, submission and subjectivity are not antithetical. Thus, the whole narrative is a repetition of history, the history of slavery with the insertion of some difference. In this parodic representation of history in order to connect with her white ancestry, Dana re-forms the past by making herself an example of individual agency. Recapturing the past allows her to offer her contemporary worldview or perspective on the historical events, with the ultimate purpose of a transformation or change.

Submission implies the possibility of resistance; it takes the form of a performance, a game that eventually allows a certain agency or subjectification. Indeed, Dana adopts a strategy of survival in order to overcome adversity in the oppressive realm of slavery. It is a strategy that was common among slaves. They used it as a veil or a mask in order to protect themselves against brutalities from whites. Echoing Ralph Ellison's Invisible Man (1984), this attitude for 
survivorship has become an important legacy, regularly taught as a lesson to slaves by their fellow blacks. In the following passage, Luke, a slave teaches Nigel, another slave how to behave in whites' presence. "“Don't argue with white folks,' he had said. 'Don't tell them "no." Don't let them see you mad. Just say "yes, sir." Then go 'head and do what you want to do. Might have to take a whippin' for it later on, but if you want it bad enough, the whippin' won't matter much"' (102). It is exactly the same strategy of resignation and resistance the grandfather of the unnamed protagonist has taught his son on his deathbed in Ralph Ellison's Invisible Man: "Live with your head in the lion's mouth. I want you to overcome "em with yeses, undermine 'em with grins, agree 'em to death and destruction, let 'em swoller you till they vomit or bust wide open'” (1984:17).

Resorting to her historical knowledge of the slave's code, Dana adopts the same mentality in her struggle against the debasing and annihilating racist impulses of Tom Weylin, the white plantation owner. In one of their interactions, Dana does not hesitate to put into practice what she has learned: "Then I looked away, remembering that I was supposed to be a slave. Slaves lowered their eyes respectfully. To stare back was insolent. Or at least, that was what my books said" (67). Imbued with a background knowledge of the antebellum era, she does her utmost to accommodate and stand almost passively whatever is done to her. For instance, talking about the role she has to play in Tom Weylin's family, she asserts: "I was the worst possible guardian for him - a black to watch over him in a society that considered blacks subhuman, a woman to watch over him in a society that considered women perennial children" (69).

Nevertheless, Dana is relentlessly determined to accept her subjection to the atrocities of human subjugation, with the secret purpose of acting upon Rufus, the heir of the Weylins' plantation: "But I would help him as best I could. And I would try to keep friendship with him, maybe plant a few ideas in his mind that would help both me and the people who would be his slaves in the years to come. I might even be making things easier for Alice" (69). She makes it her mission to try her best and alleviate the suffering of the slaves by transforming Rufus into a good master. It is in that purpose of protecting herself and the other slaves that she exposes herself to victimhood.

In addition to her knowledge of slavery and oppression that commands her survival strategy, Dana has developed resources and abilities to adjust to her condition from what she learns from other slaves. As she admits, "I liked to like listen to them talk sometimes and fight my way through their accents to find out more about how they survived lives of slavery. Without knowing it, they prepared me to survive" (99). Meanwhile, in the process, Dana is allowed an evaluative re-presentation for a new signification of what has happened according to official history or the history that is embodied in institutional records. Indeed, she makes the past a form of recuperation as well as a form of exorcism. To make meaning and gain an understanding of the past, Dana does not simply tell the painful experiences of her ancestors, she unflinchingly accepts to endure the trials of slavery, and sometimes realizes her personal limits when she draws a parallel between her experience and what her ancestors have endured:

Dana: “'Strength. Endurance. To survive, my ancestors had to put up with more than I ever could. Much more. You know what I mean.' 
Kevin: "'No, I don't. you're working yourself into a mood that could be suicidal if you're not careful'" (49)

From her scholastic knowledge of history, and before coming to the conclusion that "Slavery was a long slow process of dulling" (202), Dana is prone to construe biased ideas about slaves' attitude and mentality. For instance, elaborating on Sarah, one of the slave women's attitude, she hastily concludes that she lacks resilience because she stays in her place:

She had done the safe thing - had accepted a life of slavery because she was afraid. She was the kind of woman who might have been called 'mammy' in some other household. She was the kind of woman who would be held in contempt during the militant nineteen sixties. The house-nigger, the handkerchief-head, the female Uncle Tom - the frightened powerless woman who had already lost all she could stand to lose, and who knew as little about the freedom of the North as she knew about the hereafter. I looked down on her myself for a while. Moral superiority. Here was someone even less courageous than I was. That comforted me somehow (159).

However, drawing on her own experience of the past, she later realizes that this conception of moral superiority she thought she had on Sarah is totally naïve and mistaken. This understanding of black powerlessness is subsequent to her own failure and incapacity to escape despite her being educated, which highly contrasts with the feat of one historical figure, Harriet Tubman, an uneducated slave woman, who had escaped and helped many slaves escape from their masters' control:

Nothing in my education or knowledge of the future had helped me to escape. Yet in a few years an illiterate runaway named Harriet Tubman would make nineteen trips into this country and lead three hundred fugitives to freedom. What had I done wrong? Why was I still slave to a man who had repaid me for saving his life by nearly killing me. Why had I taken yet another beating. And why ... why was I so frightened now - frightened sick at the thought that sooner or later, I would have to run again? (195)

When she confronts her experience with the experiences of her ancestors, Dana develops a new consciousness or understanding which is significant and justifies her transformative return to the past. She even moves a step further to confess that compared to her ancestors who participate in history as actors, her re-living of the past is not but a game, since her participation in history is somewhat limited to her role as a narrator. In that game, she is only performing the role of representing the past instead of participating in the socio-historical process. Undoubtedly, this awareness testifies and underscores her ancestors' moral superiority over her:

I began to realize why Kevin and I had fitted so easily into this time. We weren't really in. we were observers watching a show. We were watching history happen around us. And we were actors. While we waited to go home, we humored the people around us by pretending to be like them. But we were poor actors. We never really got into our roles. We never forgot that we were acting (104).

Nevertheless, in her will to reconstruct the slave past, Dana intends to intrude in history so as to effect some change. As Trouillot (1995) indicates, "Not only can history mean either the sociohistorical process or our knowledge of that process, but the boundary between the two 
meanings is often quite fluid" (3). Dana's role as the narrator overlaps with the historical process that she intends to influence using her relationship to Rufus as a site of negotiation. This historical agency is against the norms of the slave tradition; and it was impossible in the past. For Kevin, her white husband, Dana is "gambling against history" (86). He explains, "“It still might not work. After all, his environment will be influencing him every day you're gone. And from what I've heard, it's common in this time for the master's children to be on nearly equal terms with the slaves. But maturity is supposed to put both in their "places"" (86). Yet, Dana is decided to take a chance, and she sticks to her plan; that is coaching Rufus into abandoning the slave culture for her own sake and for the sake of the other slaves: "What else can I do? I've got to try, Kevin, and if trying means taking small risks and putting up with small humiliations now so that I can survive later, I'll do it'" (86).

In confronting the past, the physical and psychological trauma of living in the past, Dana is simultaneously gaining agency through what can be termed as the "authority of experience." It is Dana's opportunity to understand her great-grandmother's hardships as a black woman in the 19th century, and above all, to speak for herself, to be the subject of her own story instead of being the object in the hegemonic version of history.

To achieve this self-constructed identity, Dana immerses into the nightmarish world of slavery with subject position; that is from the slave's perspective. She tries to bridge the gap between the official accounts of slavery and the lived experience of her ancestors. She represents facts by herself, and in doing so, she achieves narrative authority over the past. In her "Redeeming History. Toni Morrison's Beloved," Helene Moglen (1997) writes,

At the border of the unconscious and the conscious - or, in Lacanian terms, at an edge between the Imaginary and the Symbolic - the fantastic, through all its genres, struggles to undo the processes of signification and differentiation that are fundamental to psychological and social experience. Its narratives reflect the encounter between the I and the not-I that takes place in the development and enculturation of the self. (202)

As Cristina Şandru (2008) indicates, "One central thematic element that various forms of magical realist fiction share is the 'play with history,' (the questioning of ontological background of historical reality) or the redefinition and recreation of official accounts of historical events" (26). Dana "plays with history" or "gambles against history" by making fluid or transgressing the limit between the roles of actor and narrator. This ambivalence is quite apparent in her way of presenting the scene when she saw the slaves that Rufus has decided to sell:

Dana: I thought, that could be me - standing there with a rope around my neck waiting to be led away like someone's dog!' I stopped, looked down at him, then went on softly. 'I'm not property, Kevin. I'm not a horse or a sack of wheat. If I have to seem to be property, if I have to accept limits on my freedom for Rufus's sake, then he also has to accept limits - on his behavior toward me. He has to leave me enough control of my own life to make living look better to me than killing and dying (275).

Kevin: 'If your black ancestors had felt that way, you wouldn't be here,' said Kevin 
Dana: 'I told you when all this started that I didn't have their endurance. I still don't. some of them will go on struggling to survive, no matter what. I'm not like that' (275).

In the reiteration of the ancestral experience, and as a tangible symptom of Dana's psychic trauma, she is identified with Alice Greenwood. Indeed, Dana is presented as an alternative version of Alice Greenwood, her biological and spiritual ancestor, and she re-construes the historical scenario by confronting slavery with agency. In other words, Dana is a revisionary version of Alice, who could not endure the coercive power of slavery. By surviving, Dana, as an alternative version of Alice, changes history. The backwards travels or the anachronisms allow Dana to re-construct the past, and achieve a deeper understanding of the traumatic experiences of slavery. Those anachronisms in which Kevin, Dana's white husband also participates are supposed to engender an American consciousness.

Referring to this transformative historical return, Levy-Hussen (2016) contends that Butler wishes to "rehabilitate the repudiated ancestral slave as a symbol of resilience, rather than defeat, and as the avatar of a more expansive, nuanced vision of heroic black identity" (loc.1337) Levy-Hussen (2016) holds this interpretation from Butler's own meditation on writing Kindred: "I was trying to get across the kind of emotional and psychological stones that slavery threw at people" (quoted by Levy, loc. 1355).

Magical realism, as the narrative strategy in Kindred, allows the suppressed or the silenced to find its way into the text. As Spaulding (2005) elaborates, "By erasing the boundaries of time and space, African American writers claim the authority to re-form history from their present perspective and compel readers to embrace an expansive, imaginative, and liberating representation of slavery" (19). The magical realist universe proposed in Kindred is an artificial world whose purpose is to actualize a silenced reality for a new awareness. History operates here as a transformative or redemptive means in so far as it engenders mutual recognition. In the ultimate act of killing Rufus at the end of the novel, Dana experiences her subject position that is acquainted with this concluding fact on slavery: "A slave was a slave. Anything could be done to her. And Rufus was Rufus - eratic, alternatively generous and vicious. I could accept him as my ancestor, my younger brother, my friend, but not as my master, and not as my lover" (290).

In reconfiguring the past, Dana claims authority toward the narrative construction and therefore records herself in history. Thus, owing to its interpretive characteristic, history, as a narrative representation of real events that happened in the past is deployed in Kindred as a site of struggle. Dana's redemptive return to the past can be justified by the fact that history has left blank spaces, absences and deferral in her past. In order to prove that she is "no freak of history," she goes back to fill in and to redefine master/slave relationships. Speaking from the margin, Dana breaks away from the discourse perceived as central. She gains access to narrative truth, and using her own perception and construction of reality, she creates an alternative world, a metafiction to amend the existing reality of slavery.

Ultimately, this appropriation of historical narrative is likely to bring her to a new and unbiased understanding of the ways her ancestors have endured slavery. Like the anonymous character who refuses to blame his grandparents in Ralph Ellison's Invisible Man (1984), she has also reached this conclusion: "I am not ashamed of my grandparents for having been 
slaves. I am only ashamed of myself for having at one time been ashamed (17). As Haley V. Manis (2016) observes in "Reconciling the Past in Octavia Butler's Kindred," "He [Kevin] and Dana both experience the South in a way that changes their perspectives in the present about the world and each other. Kevin redeems himself in that way by realizing the truth that no one else could reach" (48).

\section{CONCLUSION}

The past has an enduring power: slavery has shaped the discursive embodiments of the African American. Yet, the past is not just a burden. It is the key that opens the door for a better adjustment to the present. For the African American writer, the past and the present are interrelated and the consciousness of the past is of great importance and absolutely undeniable for any sustainable equilibrium of her being. How to adjust to the present? The answer can be found in the past, in history according to Octavia Butler's Kindred. The focus in this study has been the affirmation and evaluation of history both as an enduring and redemptive power in contemporary African American writings.

Kindred is a narrative about freedom that rejects the hegemonic or totalizing stance, a psychological meditation, which is an imaginative projection based on magical realism: a particular narrative technique. That particular narrative allows a re-assessment of the traumatized life of the enslaved, challenges the official history of slavery and articulates the African American subjectification. As a narrative mode, magical realism in Kindred functions as a "mirror-self" which serves to reveal those facets of reality that the official "regimes of truth" by whites have systematically occluded or reworked to fit their preset ideological patterns. The anachronisms allow an historical reclamation for a transformative return that serves as a way to assess the traumatized lives of the enslaved with the perspective of closing the wound of the past or overcoming it; thus, the redemptive power of history.

\section{References}

Arva, Eugene L. (2020) "Writing the Vanishing Real: Hyperreality and Magical Realism" retrieved on Google on January 17, 2020.

Baker, Houston and K. Merinda Simmons, Ed. (2015) The Trouble with Post-Blackness. New York: Columbia University Press Book.

Butler, Octavia. (1979) Kindred. Doubleday. This ebook edition has been published in 2018 by Headline Publishing Group.

Eagleton, Terry. (2003) Sweet Violence. The Idea of the Tragic. Oxford: Blackwell Publishing.

Ellison, Ralph. (1984) Invisible Man. New York: Penguin Books.

Lacapra, Dominick. (2016) “Trauma, History, Memory, Identity: What Remains?" History and Theory 55, 375-400

Laplanche, S.J. and J.-B. Pontalis. (1973) The Language of Psychoanalysis. Translated by Donald Nicholson-Smith. New York: Norton and Company.

Levy-Hussen, Aida. (2016) How to Read African American Literature. Post-Civil Rights Fiction and the Task of Interpretation. New York: New York University Press.

Manis, Haley V. (2016) "Reconciling the Past in Octavia Butler's Kindred." Electronic Theses and Dissertations. Paper 3173. https://dc.etsu.edu/etd/3173. 
Moglen, Helene. (1997) "Redeeming History. Toni Morrison's Beloved” in Female Subjects in Black and White. Race, Psychoanalysis, Feminism. Edited by Elizabeth Abel, Barbara Christian, Helene Moglen. Berkeley: University of California Press, (201220).

Sandru, Christina. (2008) "A Bakhtinian Poetics of Subversion: The Magical Realist Fiction of the 1980s in East-Central Europe." Critique. VOL. 50, NO. 1

Spaulding, Timothy A. (2005) Reforming the Past. History, the Fantastic, and the Postmodern Slave Narrative. Columbus: The Ohio University Press.

Tate, Claudia. (1998) Psychoanalysis and Black Novels. Desire and the Protocols of Race. New York: Oxford University Press.

Trouillot, Michel-Rolph. (1995) Silencing the Past. Power and the Production of History. Boston: Beacon Press. 